\title{
Human resources for supply chain management online discussion. What do the countries have to say?
}

Andrew N Brown ${ }^{1 *}$, Erin Hasselberg ${ }^{2}$, Pamela Steele ${ }^{3}$

From The 2nd People that Deliver (2nd PtD) Global Conference on Human Resources in Supply Chain Management

Copenhagen, Denmark. 29-30 October 2014

\section{Background}

PtD brings together a range of global stakeholders with expertise in SCM with a mission "to build global and national capacity to implement evidence-based approaches to plan, finance, develop, support, and retain the national workforces needed for the effective, efficient, and sustainable management of health supply chains." To ensure PtD continues to understand country experiences, an online discussion via the Independent Association of Public Health Logisticians (IAPHL) was designed to interact with a large variety of countries globally.

\section{Method}

Under the theme of 'Systematic Approaches to Human Resources for Health Supply Chains' three content experts were asked to prepare a two page evidenced brief addressing one of three sub themes. Over a four week period (April - May 2014), each brief was presented to IAPHL members and seeding questions used to promote asynchronous discussion. Moderators engaged in the discussion and used a process of thematic analysis to assess the discussion.

\section{Results}

103 contributions were made (Av. of 9 [1-17] contributors per question), 24 countries were represented (av. of 7 (112) per question). Several sub themes emerged from the three topics:

HR as a barrier. A lack of supply chain strategy and unclear patterns in decision making responsibilities

\footnotetext{
* Correspondence: anbrown.hss@gmail.com

${ }^{1}$ People that Deliver, Copenhagen, Denmark

Full list of author information is available at the end of the article
}

dominated, with an underestimation of the SC managerial competencies required.

A systematic approach. A need for SCM champions and medium-to-long term HR and SCM strategies was clear, with professionalization of the SCM workforce identified as the most significant challenge.

Education and continual professional development. Pre service education was seen as an early foundation that must be built on by competency based in-service training. A lack of resources was seen as the main barrier.

\section{Discussion}

It is clear that HR issues are a barrier to the effective running of health supply chains in many countries. Improving the professionalization of health supply chain cadres is seen as a priority by a number of countries with appropriate combinations of pre-service foundation training and competency based in-service training called for. Country based support is required to allow governments to systematically assess HR aspects of their supply chains while competent health supply chain leaders are needed to enable improvement plans to be successfully implemented.

\section{Lessons learned}

Issues concerning HR for SCM exist across a range of countries. The IAPHL discussion platform proved to be an effective forum to engage a variety of country based stakeholders concerning issues around HR for SCM.

\footnotetext{
Authors' details

${ }^{1}$ People that Deliver, Copenhagen, Denmark. ${ }^{2}$ John Snow Inc., Boston, MA., USA. ${ }^{3}$ Pamela Steele Associates (PSA) Ltd, Oxford, UK.
} 
Cite this article as: Brown et al: Human resources for supply chain management online discussion. What do the countries have to say? Journal of Pharmaceutical Policy and Practice 2014 7(Suppl 1):P5.

Submit your next manuscript to BioMed Central and take full advantage of:

- Convenient online submission

- Thorough peer review

- No space constraints or color figure charges

- Immediate publication on acceptance

- Inclusion in PubMed, CAS, Scopus and Google Scholar

- Research which is freely available for redistribution

Submit your manuscript at www.biomedcentral.com/submit 